\title{
Chrysin: Perspectives on Contemporary Status and Future Possibilities as Pro-Health Agent
}

\author{
Monika Stompor-Gorący ${ }^{1, * \mathbb{D}}$, Agata Bajek-Bil ${ }^{2}$ and Maciej Machaczka ${ }^{1,3}$ \\ 1 Department of Human Pathophysiology, Institute of Medical Sciences, University of Rzeszów, Warzywna 1a, \\ 35-310 Rzeszów, Poland; maciej.machaczka@ki.se \\ 2 Faculty of Chemistry, Rzeszow University of Technology, 35-959 Rzeszów, Poland; abajek@prz.edu.pl \\ 3 Department of Clinical Science and Education, Division of Internal Medicine, Södersjukhuset, \\ Karolinska Institutet, 11883 Stockholm, Sweden \\ * Correspondence: monika.stompor@gmail.com
}

check for updates

Citation: Stompor-Goracy, M.;

Bajek-Bil, A.; Machaczka, M. Chrysin: Perspectives on Contemporary Status and Future Possibilities as Pro-Health Agent. Nutrients 2021, 13, 2038.

https://doi.org/10.3390/nu13062038

Academic Editors: Nadia Calabriso and Maria Annunziata Carluccio

Received: 19 May 2021

Accepted: 7 June 2021

Published: 14 June 2021

Publisher's Note: MDPI stays neutral with regard to jurisdictional claims in published maps and institutional affiliations.

Copyright: (c) 2021 by the authors. Licensee MDPI, Basel, Switzerland. This article is an open access article distributed under the terms and conditions of the Creative Commons Attribution (CC BY) license (https:// creativecommons.org/licenses/by/ $4.0 /)$.

\begin{abstract}
Chrysin belongs to the group of natural polyphenols. It can be found, among others, in honey, propolis and fruits and has a wide range of biological activities, including the prevention of oxidative stress, inflammation, neurodegeneration and carcinogenesis. Being a part of the human diet, chrysin is considered to be a promising compound to be used in the prevention of many diseases, including cancers, diabetes and neurodegenerative diseases such as Alzheimer's or Parkinson's. Nevertheless, due to the low solubility of chrysin in water and under physiological conditions, its bioavailability is low. For this reason, attempts at its functionalization have been undertaken, aiming to increase its absorption and thus augment its in vivo therapeutic efficacy. The aim of this review is to summarize the most recent research on chrysin, including its sources, metabolism, pro-health effects and the effects of its functionalization on biological activity and pharmacological efficacy, evaluated both in vitro and in vivo.
\end{abstract}

Keywords: chrysin; anticancer activity; neuroprotection; antioxidants; immunomodulators

\section{Introduction}

Polyphenolic compounds, including hydroxyflavones, are common components of many plants, fruits, medicinal herbs, flowers and dietary supplements [1,2]. Due to the presence of free hydroxyl groups in various configurations, they have high antioxidant activity [3]. To polyphenols belong such compounds as quercetin, chrysin, apigenin, baicalein and their derivatives (Figure 1). Their hydroxyl groups serve as reactive centers used for the functionalization of the compounds, aiming to increase their water solubility, bioavailability and biological activity $[4,5]$.

Flavonoids with hydroxyl groups are important ingredients of humans' daily diet; therefore, they are most thoroughly studied with respect to their influence on the human organism [6,7]. These studies have been preceded by several in vitro tests in which cell lines were used [8]. Natural hydroxyflavones have a range of biological activities, including anticancer [9], antioxidative [10], anti-inflammatory [11] antiallergic [12], hepatoprotective [13] and neuroprotective ones [14]. They prevent diabetes mellitus complications, such as retinopathy, which may lead to blindness [15]. Additionally, they have antimicrobial [16] and antiviral $[17,18]$ properties. Because of their significant biological activities, they serve as basic substances for the development of new dietary supplements or foodstuffs intended for particular nutritional uses. Due to their pro-health properties, plant extracts rich in hydroxyflavonoids are used for the development of innovative recipes for desserts enriched with natural therapeutic substances, e.g., ice cream [19].

Taking into account the dynamic development of research on the role of polyphenolic compounds as therapeutic agents, the objective of this review is to summarize the current knowledge about natural sources of chrysin, its pharmacological activity and new ways 
of delivery. Moreover, recent reports about how chrysin can counteract the side-effects of some drugs used in conventional pharmacotherapy are summarized.<smiles>O=c1c(O)c(-c2ccc(O)c(O)c2)oc2cc(O)cc(O)c12</smiles>

quercetin<smiles>O=c1cc(-c2ccccc2)oc2cc(O)cc(O)c12</smiles>

chrysin<smiles>O=c1cc(-c2ccc(O)cc2)oc2cc(O)cc(O)c12</smiles>

apigenin<smiles>O=c1cc(-c2ccccc2)oc2cc(O)c(O)c(O)c12</smiles>

baicalein

Figure 1. Chemical structures of selected polyphenols.

\section{Sources of Chrysin}

Chrysin (5,7-dihydroxyflavone) belongs to natural polyphenols, which are found among others in honey [20], propolis [21] and various medicinal plants and fruits (Table 1), such as bitter melon (Momordica charantia) [22] or the wild Himalayan pear (Pyrus pashia) [23]. In terms of chemical structure, chrysin belongs to the dihydroxyflavones, with the hydroxyl groups attached to the $\mathrm{A}$ aromatic ring ( $5-\mathrm{OH}$ and $7-\mathrm{OH}$ positions), the chemical formula $\mathrm{C}_{15} \mathrm{H}_{10} \mathrm{O}_{4}$ and molar mass, $254.241 \mathrm{~g} \cdot \mathrm{mol}^{-1}$. In plants, the precursor of chrysin is the amino acid phenylalanine, which is in the first step, converted to cinnamic acid by the action of the enzyme phenylalanine ammonia-lyase on the phenylpropanoid pathway.

The most recent research also confirms the presence of chrysin in Diaphragma juglandis fructus, walnut pellicle, the flowers of Juglans regia (common walnut) [24], the leaves and fruits of doum palms (Hyphaene thebaica) [25] and also the peel of passion fruit (Passiflora edulis Sims), where it is found in the form of glycoside (chrysin-8-C-(2"-O- $\beta-6$-deoxyglucopyranosyl)- $\beta$-D-glucopyranoside, $0.35 \mathrm{mg} \mathrm{kg}^{-1}$ ) [26]. Chrysin was also identified in the medicinal herb Banxia Xiexin used in traditional Chinese medicine for the treatment of gastrointestinal diseases, where it is present in the form of 6-C-arabinoside-8-C-glucoside or as a glucuronic acid ester, i.e., chrysin-7-O-glucuronide [27]. In addition, chrysin glucuronides were also found in the aerial part of Scutellaria schachristanica [28]. Another source of chrysin is an endophytic fungus Chaetomium globosum, associated with a green marine alga (Chaetomorpha media) originating from India [29]. Chrysin and chrysin-7-O$\beta$-D-glucopyranoside are the main ingredients of the Algerian plant Cytisus villosus Pourr, which has proven antiprotozoal activity against Trypanosoma brucei [30]. Chrysin in the form of 8-C-glucopyranoside is also an ingredient of Salvadora persica, the plant with antibacterial properties recommended by the World Health Organization for the production of the toothbrush fiber [31].

Table 1. The content of chrysin in the selected sources.

\begin{tabular}{ccc}
\hline Product & Content of Chrysin & Ref. \\
\hline Manuka honey & $0.131 \mathrm{mg} / 100 \mathrm{~g}$ & {$[20]$} \\
\hline Propolis extract & $\begin{array}{c}\text { Acetone: } 14.62 \mathrm{mg} \mathrm{g}^{-1} \\
70 \% \text { EtOH: } 18.64 \mathrm{mg} \mathrm{g}^{-1} \\
96 \% \text { EtOH: } 11.41 \mathrm{mg} \mathrm{g}^{-1}\end{array}$ & {$[21]$} \\
\hline Diaphragma juglandis fructus & Up to $40 \mathrm{mg} \mathrm{g}^{-1}$ & {$[24]$} \\
\hline Hyphaene thebaica & $0.083 \mathrm{mg} \mathrm{g}^{-1}$ & {$[25]$} \\
\hline Chaetomium globosum & $13 \%$ & {$[29]$} \\
\hline Cytisus villosus & $4 \mathrm{mg} \mathrm{kg}^{-1}$ & {$[30]$} \\
\hline
\end{tabular}

Because of the therapeutic properties of chrysin, research has been undertaken on its production in the hairy roots of plants, for example, Scutellaria bornmuelleri, obtained 
by genetic modification with the help of Agrobacterium rhizogenes [32]. The nutraceutical properties of plants rich in antiradical metabolites, including chrysin, encourage researchers to seek other methods of synthesis of such compounds, for example, using callus cell cultures obtained from different parts of the plants [33].

\section{Metabolism of Chrysin}

An in vivo study in humans after oral administration of chrysin (400 mg) indicated that this is a compound with low bioavailability, depending mainly on fast metabolism in the gastrointestinal tract [34]. In search of the metabolic pathways of natural compounds, microbial and enzymatic transformations were employed. Receiving flavonoid derivatives of pharmaceutical importance by means of biotransformation is a commonly known method. Modifications of the main skeleton of flavonoids have strong influences on their biological activity. In some cases, biological methods of synthesis are the only possible way to achieve the compounds, which are very difficult to synthesize by chemical methods. The team of Liu et al. [35] identified a range of enzymes belonging to flavone hydrolases and methyltransferases, which are responsible for the synthesis of chrysin and its derivatives, such as baicalin and wogonin, in the culture of Saccharomyces cerevisiae yeasts. Another study [36] described that metabolism of chrysin in Rhodotorula glutinis over $72 \mathrm{~h}$ started from an initial C-8 hydroxylation of the substrate to norwogonin (31\% yield), followed by the A-ring cleavage to 4-hydroxy-6-phenyl-2H-pyran-2-one as the final product. Meanwhile, ten-day biotransformations of chrysin in the cultures of Beauveria bassiana AM 278, Aquilegia coerulea AM 93 and Absidia glauca AM 177 led to chrysin 7-O- $\beta$ D-(4"-O-methyl)-glucopyranoside and chrysin 7-O- $\beta$-D-glucopyranoside in $14-23 \%$ yields (Figure 2) [37].
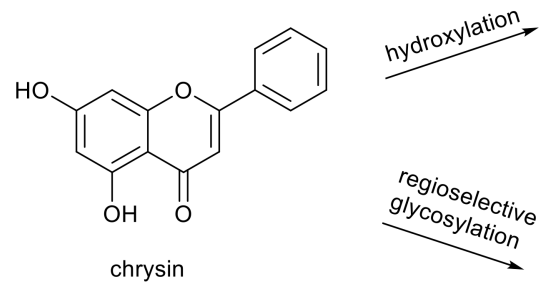<smiles>O=c1cc(-c2ccccc2)oc2c(O)c(O)cc(O)c12</smiles>

norwogonin
A-ring cleavage<smiles>O=c1cc(O)cc(-c2ccccc2)o1</smiles>

4-Hydroxy-6-phenyl-2H-pyran-2-one (Rhodotorula glutinis culture)<smiles>O=c1cc(-c2ccccc2)oc2cc(O[C@@H]3O[C@H](CO)[C@@H](O)[C@H](O)[C@H]3O)cc(O)c12</smiles>

chrysin 7-O- $\beta$-D-glucopyranoside

(Absidia coerulea AM 93 and A. glauca AM 177 culture) or<smiles>CO[C@H]1C(CO)O[C@@H](Oc2cc(O)c3c(=O)cc(-c4ccccc4)oc3c2)[C@H](O)[C@@H]1O</smiles>

chrysin 7-O-ß-D-(4"-methyl)-glucopyranoside (Beauveria bassiana AM 278 culture)

Figure 2. Metabolism of chrysin in Rhodotorula glutinis, Absidia coerulea AM93, Absidia glauca AM 177 and Beauveria bassiana AM 278 cultures.

The two dominant products of chrysin metabolism in humans and in mice are chrysin7-sulfate (C7S) and chrysin-7-glucuronide (C7G) (Figure 3) [34,38]. After the oral administration of chrysin $\left(20 \mathrm{mg} \mathrm{kg}^{-1}\right)$ to mice, the $C_{\max }$ of chrysin was only $10 \mathrm{nmol} \mathrm{L}^{-1}$, while 160 and $130 \mathrm{nmol} \mathrm{L}^{-1}$ peak plasma concentrations of C7S and C7G were quantified, respectively [38]. In another study, a $400 \mathrm{mg}$ dose of chrysin was administered orally to healthy human volunteers, after which C7S reached approximately 30 -fold higher AUC0- $\infty$ values compared to chrysin (420-4220 ng. $\mathrm{mL}^{-1} \cdot \mathrm{h}$ vs. $3-16 \mathrm{ng} \cdot \mathrm{mL}^{-1} \cdot \mathrm{h}$, respectively) [34]. Based on previous studies, chrysin is a potent inhibitor of some biotransformation enzymes (e.g., 
CYP3A4, CYP2C9 and xanthine oxidase) and is also able to affect drug transporters (e.g., P-glycoprotein) [39]. Additionally, Bojić et al. [40] proved the inhibitory activity of chrysin to cytochrome $\mathrm{P}_{450}$ monooxygenase CYP1A2.<smiles>O=c1cc(-c2ccccc2)oc2cc(OS(=O)(=O)O)cc(O)c12</smiles>

chrysin-7-sulfate

(C7S)<smiles>O=C(O)C1OC(Oc2cc(O)c3c(=O)cc(-c4ccccc4)oc3c2)C(O)C(O)C1O</smiles>

chrysin-7-glucuronide (C7G)

Figure 3. Two dominant products of chrysin metabolism in humans.

In an ex vivo study by Labib et al. [41], it was demonstrated that chrysin is not metabolized by the pig intestinal microflora, unlike its structural analogs naringenin, quercetin or hesperetin, which undergo degradation to low-molecular-weight compounds (3,4 dihydroxytoluene, phloroglucinol). In the case of hesperetin, it is preceded by the O-demethylation to eriodictyol.

\section{Biological Activity}

\subsection{Anticancer Activity of Chrysin and Its Derivatives}

Among the pharmacological activities of chrysin, its anticancer properties are well documented [42]. It acts through the induction of apoptosis and inhibition of cancer cell migration $[43,44]$. Its antitumor properties were proven for various malignancies, including prostate cancer (DU 145, PC-3) [45], breast cancer [46], lung cancer (A549), liver cancer (HepG2), colon cancer (SW480) [47] and pancreatic cancer (SW1736, 8505C) [48], and also epidermoid carcinoma (A431) [49], glioblastoma (T98, U251, U87) [50] and human uveal melanoma (SP6.5, M17) [51]. According to the Salama and Allam study [52], chrysin and daidzein exerted anticancer activity against SW620 cells, which was associated with a decrease in the protein expression of p-ERK/ERK and p-AKT/AKT.

Moreover, the anticancer activity of the amino acid chrysin derivatives obtained by chemical synthesis has been proven [53]. Thus, the development of new chrysin derivatives with potentially better antitumor properties is reasonable [54-56].

Some long-chain ester derivatives of chrysin are also known to have good biological activity. An example is 7-O-myristyl chrysin, a compound with a flexible structure, considerably good solubility and activity against liver cancer cell lines 5.4 times greater than chrysin (IC50 - compound concentration leading to $50 \%$ inhibition of cell proliferation was $74.97 \mu \mathrm{mol} \mathrm{L}^{-1}$ ) [57].

Meanwhile, the replacement of the oxygen at C-4 in chrysin with selenium resulted in increased antioxidant activity, both in aqueous and lipid media. It was also confirmed that the higher $\mathrm{pH}$, the faster the reaction of the selenium chrysin derivatives with the $\mathrm{HOO}$ radical [58].

Another method of modification is halogenation. In the most recent research, it was shown that substitution of chrysin with chlorine increases the binding affinity to human protein kinase $\mathrm{hCK} 2 \alpha$, which is a therapeutic target for new inhibitors used in the treatment of cancer due to the strong correlation between malignancy and abnormally high activity of this protein in cancer cells. It was observed that 8-chlorochrysin (Figure 4) had stronger binding activity to hCK2 $\alpha$ than the reference CK2 inhibitor, 4,5,6,7-tetrabromo1H-benzotriazole [59]. 
<smiles>CCC(C)C(NC(=O)CCCCCCOc1cc(O)c2c(=O)cc(-c3ccccc3)oc2c1)C(=O)O</smiles>

chrysin amino acid derivative<smiles>C=C(CCCCCCCCCCCCC)Oc1cc(O)c2c(=O)cc(-c3ccccc3)oc2c1</smiles><smiles>CCCC(c1ccc(O)cc1)C1C=CC=C1</smiles>

selenium chrysin derivative<smiles></smiles>

porphyrin-chrysin derivative

Figure 4. Examples of chrysin derivatives with proven anticancer activity.

Moreover, chrysin and its porphyrin derivatives can be used in the non-invasive photodynamic therapy of human gastric cancer cells (MGC-803) and human cervical cancer cells (HeLa) [60].

\subsection{Influence of Chrysin on Side Effects Associated with Pharmacotherapy}

Nowadays, the goal of medical science is to find and identify safe compounds, free from side-effects, which may be used as therapeutics in humans. It was proven that natural substances may be effective adjuvants in the treatment of many diseases, not only in the case of immunodeficiency but also in the prevention of a range of disorders in patients with properly functioning immune systems.

Due to the strong interaction of chrysin metabolites (mainly chrysin-7-sulfate) with human serum albumins (HAS), the intake of chrysin with food may affect the albumin-binding properties of some drugs [61]. In this way, it affects the pharmacokinetics, biological activity and half-life of a drug, as it is the amount of a free drug in the blood (unbound to plasma proteins) that has a therapeutic effect.

Commonly used anticancer drugs, such as mitomycin C, by interaction with biological molecules, can cause genetic damage in healthy cells, for example, in the liver, kidneys or bone marrow. In addition, they can increase the activity of intracellular antioxidant enzymes and increase lipid peroxidation. Meanwhile, administration of chrysin in a dose of $40 \mathrm{mg} \mathrm{kg}^{-1}, 24 \mathrm{~h}$ prior to the treatment with mitomycin C, caused regression of the genotoxic effect, which also resulted partly from the high antioxidant activity of chrysin [62].

Currently, there is ongoing research on using chrysin in combination therapy, to enhance the efficiency of chemotherapeutics such as docetaxel [63], cisplatin and camptothecin [64]. Moreover, chrysin regulates abnormal changes in enzyme activities induced by commonly used anticancer drugs, such as cyclophosphamide. This is confirmed by the results of the study on the effect of chrysin on the regulation of the pentose phosphate pathway enzymes (playing a pivotal role in cancer cell proliferation) and the enzymes of the reduced glutathione and thiorodexin system, which take part in intramolecular ROS removal [65].

Similar conclusions were drawn by the group of Taslimi et al. [66]. Chrysin administered to rats ( 25 and $50 \mathrm{mg} \mathrm{kg}^{-1}$ ) seven days prior to treatment with a single dose of cyclophosphamide $\left(200 \mathrm{mg} \mathrm{kg}^{-1}\right)$ considerably reduced the toxic effects of this drug by regulating the activity of metabolic enzymes of the liver (e.g., carbonic anhydrase, aldose reductase, paraoxonase- $1, \alpha$-glycosidase, acetylcholinesterase), heart and brain (butyrylcholinesterase). Administered in combination with methotrexate, chrysin has 
a protective effect on methotrexate-induced testicular damage in rats [67]. Darendelioglu et al. [68] proved that chrysin reversed the harmful side-effects of some nonsteroidal antiinflammatory drugs, such as diclofenac. The in vitro study was conducted on the SH-SY5Y human neuroblastoma cell line. Moreover, chrysin, probably due to its antioxidant activity, ameliorates isoniazid-induced changes, such as brain oxidative damage, inflammation and apoptosis [69]. According to an in vivo study on rats, chrysin (in a dose of $50 \mu \mathrm{g} \mathrm{mL}^{-1}$ ) co-administered with paracetamol increased the absorption of this drug [70].

\subsection{Hepatoprotective Effects of Chrysin}

The most important risk factors for liver damage include excessive alcohol consumption, pharmaceuticals and hepatoxic substances, and also an unhealthy diet and being overweight or obese. In clinical practice, for evaluation of the stage of liver pathology, the most common biochemical tests are used. They include the activity of serum alanine aminotransferase (ALT), aspartate aminotransferase (AST) and alkaline phosphatase (ALP), the concentrations of bilirubin and albumins in plasma and the international normalized ratio (INR).

According to the most recent reports, chrysin has a positive effect on the liver by protecting the cells from toxic substances. It induces the secretion of very-low-density lipoproteins (VLDL) and reduces liver fat accumulation in non-alcoholic fatty liver disease (NAFLD) caused by a diet deficient in methionine and choline [71]. It also prevents hepatic necrosis. The group of Mohammadi et al. [72] proved that chrysin decreased the levels of liver enzymes (ALT, AST and ALP), which were previously increased by the use of acetaminophen. It has a protective effect on HepG2 hepatic cells damaged by ethanol. Chrysin, along with other ingredients of propolis, suppresses specific signaling pathways, i.e., ERK1/2 phosphorylation, AHR nuclear translocation and CYP1A1 expression [73]. Administration of chrysin prevents oxidative damage in the liver and kidneys induced by long-term alcohol consumption. Tests on Wistar rats proved that chrysin restored normal levels of oxidative stress markers, such as glutathione peroxidase, catalase and glutathione reductase [74]. Due to the proven antioxidant, anti-inflammatory and antifibrotic properties of chrysin, it is a promising agent for the treatment of non-alcoholic fatty liver disease (NAFLD) [75]. On that basis, Fatemi et al. [76], in an in vivo study, determined the mechanisms associated with the possible protective effects of chrysin against sodium arsenite-induced liver damage.

\subsection{Chrysin in Skin Diseases}

Chrysin has the ability to attenuate psoriasis-like skin lesions [77]. Its hydroxyethylated derivatives obtained by gamma irradiation may find an application in the treatment of atopic dermatitis because they decrease the levels of pro-inflammatory cytokines IFN- $\gamma$, IL-5, IL-4 and IL-17 [78]. In addition, by targeting I KB kinase in the atopic dermatitis-like inflammatory microenvironment, chrysin inhibits NF- $\mathrm{kB}$-dependent CCL5 transcription [79].

Administration of chrysin to BALB/c mice with dermatitis induced by 2,4 dinitrochlorobenzene and the house dust mite resulted in reduced levels of blood histamine and inhibited the secretion of Th1, Th2, Th17, CCl17 and CCl22 cytokines. In addition, chrysin inhibited the expression of IL-33 [80], and therefore, may find an application in the treatment of atopic dermatitis and skin allergy diseases. Similar conclusions were drawn by Song et al. [78], who proved the anti-inflammatory influence of the chrysin derivatives, obtained by gamma irradiation of chrysin on atopic dermatitis-like skin lesions in Balb/c mice. Moreover, it has been confirmed that chrysin protects human epidermal keratinocytes from UVA- and UVB-induced damage [81]. What is more, chrysin also protects the skin from photoaging and melanogenesis [82].

\subsection{Chrysin in Neurodegenerative and Eye Diseases}

Polyphenolic compounds have neuroprotective properties, improving processes of memorization. Chrysin also has such an activity and improves the processes involved 
in memory [83]. It regulates neurogenesis in memory loss due to aging [84]. It has also neuroprotective effect on SH-SY5Y neuronal cells treated with diclofenac [68]. The neuroprotective activity of chrysin may be used in the future to treat neurodegenerative diseases, including Parkinson's disease [85].

The accumulation of D-galactose induces brain aging due to oxidative stress and inflammation, leading to neuronal cell damage and memory loss. The administration of chrysin at the doses of 10 or $30 \mathrm{mg} \mathrm{kg}^{-1}$ in rats with D-galactose-induced memory disorders reversed neuronal pathological changes and attenuated the memory impairments associated with aging [84].

The most recent research suggests that chrysin may be used to treat eye diseases leading to blindness, such as macular degeneration or choroidal neovascularization [86], and also autoimmune diseases [87].

Because of the proven in vivo activity of chrysin in the inhibition of choroidal neovascularization (CNV) and in downregulation of HIF- $1 \alpha$ and VEGF expression in rats with diode laser-induced $\mathrm{CNV}$, chrysin is a promising agent to combat age-related macular degeneration (AMD) that may lead to vision loss in elderly people [86].

\subsection{Other Biological Effects of Chrysin}

Chrysin has an influence on the biosynthesis of sphingolipids, which may be associated with a reduction of oxidative stress that depends on levels of ceramides in the organism [88]. It has antiviral properties against such viruses as human rhinoviruses (HRV) [89], influenza H1N1 [90], coxsackievirus B3 (CVB3) [91] and others. It also has an antiallergic activity, which was confirmed in a study on its influence on airway inflammation. Administered at a dose of $50 \mathrm{mg} \mathrm{kg}^{-1}$ daily in a mouse model, chrysin significantly suppressed airway hyperresponsiveness to acetylcholine chloride, caused by ovalbumin. In addition, chrysin decreased total immunoglobulin $\mathrm{E}(\mathrm{IgE})$ levels in serum and the total number of inflammatory cells and eosinophils in BALF [92]. Because of its antiproliferative and pro-apoptotic activity, chrysin plays a protective role in benign prostatic hyperplasia associated with testosterone, commonly affecting men in their sixties [93]. According to the newest reports, reduction of oxidative stress achieved after administration of chrysin leads to the conclusion that this compound can be employed in the treatment of acute pancreatitis [94]. Chrysin also has antinociceptive properties in diabetes mellitus complications, considerably affecting quality and length of life, such as diabetic neuropathy [95].

What is more, chrysin has the ability to regulate metabolism. It shows a moderate ability to block the transcripts that regulate the rate-limiting enzymes involved in the biosynthesis and absorption of cholesterol [96]. According to the most recent reports, chrysin can reduce lipid accumulation by downregulating the inflammation-related target proteins ANXA2 and HSP-60, and thus may play a significant role in the treatment of obesity [97]. It also has proven anti-anxiety activity; however, in the case of chronic use, it may be addictive, similar to benzodiazepines [98]. Rodríguez-Landa et al. [99], in an in vivo study, demonstrated that chrysin $\left(2 \mathrm{mg} \mathrm{kg}^{-1}\right)$ prevents anxiety-like behavior by the action on $\gamma$ aminobutyric acid-A $\left(\mathrm{GABA}_{\mathrm{A}}\right)$ receptors. Differences in the mechanisms involved in GABA receptors' modulation by some flavonoids compared with classic benzodiazepine modulation were reported by Goutman et al. [100]. According to the results of this study, chrysin, in the micromolar range, inhibits ionic currents mediated by $\mathrm{GABA}_{\mathrm{A}}$ and $\mathrm{GABA}_{\mathrm{C}}$ receptors.

Chrysin may find an application in the treatment of gynecological diseases, such as endometriosis, which may lead to infertility. Research with the use of human endometriotic cells derived from the cervix (End1/E6E7) and vagina (VK2/E6E7) revealed that chrysin suppressed the proliferation and induced apoptosis of these cells by affecting the cell cycle, changing the cytosolic calcium level, affecting the generation of reactive oxygen species and by inactivating the PI3K signaling pathways [45].

Kseibati et al. [101] described a positive effect of chrysin administered orally at a dose of $50 \mathrm{mg} \mathrm{kg}^{-1}$ on bleomycin-induced pulmonary fibrosis. Chrysin reduced hydroxyproline 
content, decreased expression of transforming growth factor- $\beta 1$ (TGF- $\beta 1$ ) protein, reduced the activity of lactate dehydrogenase (LDH) and decreased lipid peroxidation.

Multiple sclerosis is a chronic disease of the central nervous system, which may cause serious disability. The exact cause of multiple sclerosis is unknown, though it is known that short, non-coding, single-stranded microRNA molecules are important expression regulators of the genes associated with MS-pathophysiology. Del Fabbro et al. [102] demonstrated that 25-day chrysin supplementation $\left(20 \mathrm{mg} \mathrm{kg}^{-1}\right)$ decreased microRNAs-21 and 155 expression levels changed in experimental autoimmune encephalomyelitis (EAE), induced by myelin oligodendrocyte glycoprotein (35-55) peptide in C57BL/6 mice.

Plant extracts containing chrysin have valuable antimicrobial properties [103], which served as inspiration for the development of innovative packaging materials for industrial purposes containing substances with antioxidant and antibacterial properties, such as chrysin, apigenin and lutein. Although these materials have reduced tensile strength, they have enhanced UV-vis light barrier and antibacterial activity. The film containing chrysin had the highest antibacterial activity against Escherichia coli, Salmonella typhimurium, Staphylococcus aureus and Listeria monocytogenes [104]. It is common knowledge that propolis and various kinds of honey containing chrysin have an antifungal activity [105-107], which depends on the thermal processing of honey.

Pharmacological Effects of Chrysin Complexes

One of the techniques used to improve the solubility of poorly soluble substances is complexation, including the formation of chrysin complexes with metal ions.

The complexation of chrysin with transition metal ions leads to the generation of novel metallodrugs with improved pharmacological and biochemical properties. Recently, it was described that, for example, chrysin complexes with zinc (II) have an antioxidant potential [108], with magnesium (II) have antitumor activity against lung cancer (A549) and are non-toxic against normal human fibroblasts [109], and with La (III) are characterized better anticancer and DNA binding effects than chrysin [110]. According to the physiological studies described by Ravishankar et al. [111], ruthenium-conjugated chrysin analogs may be a basis to develop new antithrombotic drugs (Table 2). Furthermore, Ravishankar et al. [111] and Marques et al. [112] described novel ruthenium conjugates of chrysin as anticancer composites.

Table 2. Novel chrysin complexes and their biological effects.

\begin{tabular}{|c|c|c|}
\hline Complex & Activity & Ref. \\
\hline Zinc(II)-chrysin & Antioxidant potential & [108] \\
\hline Magnesium(II)-chrysin & Antitumor effect against lung cancer A549 cells & [109] \\
\hline Ru-thio-chrysin complex & $\begin{array}{l}\text { Four-fold greater inhibition of platelet function and } \\
\text { thrombus formation in vitro than chrysin }\end{array}$ & [111] \\
\hline Ruthenium(II) trithiacyclononane complexes of chrysin & $\begin{array}{c}\text { Anticancer activity } \\
\text { MG-63 (osteosarcoma), PC-3 (prostate) } \\
\mathrm{IC}_{50}=146.2 \mu \mathrm{M}, \mathrm{MCF}-7 \text { and MDA-MB-231 (breast } \\
\text { adenocarcinoma) } \mathrm{IC}_{50}=180.6 \mu \mathrm{M}\end{array}$ & [112] \\
\hline $\begin{array}{c}\mathrm{Ga}(\mathrm{III}) \text {-chrysin-imidazole complex displayed the highest } \\
\text { anticancer efficacy against all cancer cell lines with } \mathrm{IC}_{50} \\
\text { values in the low micromolar range }(<1.18 \mu \mathrm{M}) \text {, a result } \\
\text { worth further investigation }\end{array}$ & $\mathrm{IC}_{50}$ values in the low micromolar range $(<1.18 \mu \mathrm{M})$ & [113] \\
\hline $\mathrm{Al}(\mathrm{III}), \mathrm{Ga}(\mathrm{III}), \mathrm{In}(\mathrm{III})$ complexes & Not tested & [114] \\
\hline $\begin{array}{c}\text { Titanium(IV), iron(III) and manganese(II) complexes of } \\
\text { chrysin- } 4^{\prime} \text {-sulfonate }\end{array}$ & Not tested & [115] \\
\hline Chrysin- $\mathrm{Pb}(\mathrm{II})$ & Antioxidant activity & [116] \\
\hline
\end{tabular}


Table 2. Cont.

\begin{tabular}{|c|c|c|}
\hline Complex & Activity & Ref. \\
\hline Chrysin-VO(IV) & Antitumoral, antioxidant & [117] \\
\hline $\begin{array}{l}\mathrm{Cu}(\mathrm{II}) \text { complexes of chrysin with 2,2'-bipyridine and } \\
\text { substituted 1,10-phenanthrolines }\end{array}$ & Antioxidant activity & [118] \\
\hline $\begin{array}{c}\mathrm{Cu}(\mathrm{II}) \text {-chrysin } \\
\mathrm{Cu}(\mathrm{II}) \text {-chrysin-1,10-phenanthroline } \\
\left.\mathrm{Cu}_{2}(\mathrm{~L})_{2}(\text { phen })_{2}\right]\left(\mathrm{NO}_{3}\right)_{2} \cdot \mathrm{MeOH} \\
\mathrm{Cu}(\mathrm{II}) \text {-chrysin-2,2'-bipyridine } \\
\mathrm{Cu}(\mathrm{L})(\text { bipy })(\mathrm{MeOH})]\left(\mathrm{NO}_{3}\right) \cdot \mathrm{MeOH}\end{array}$ & $\begin{array}{l}\text { A549 and H1299 lung cancer cell lines after } 24 \mathrm{~h} \text { of } \\
\text { exposure exhibit enhanced solubility } \\
\text { and bioavailability } \\
\text { and also improved cytotoxic and genotoxic activity } \\
\text { compared to free chrysin }\end{array}$ & [119] \\
\hline Oxidovanadium (IV) complexes with chrysin & Anticancer activity & [120] \\
\hline Chrysin-amino-appended $\beta$-cyclodextrins & $\begin{array}{l}\text { Anticancer (A549, HT-29, HCT116) and } \\
\text { antioxidant activity }\end{array}$ & [121] \\
\hline $\begin{array}{l}\text { Chrysin complexes with two cyclodextrins } \\
\text { (CDs)-(2-hydroxypropyl)- } \beta \text {-cyclodextrin (HPBCD) and } \\
\text { random methyl- } \beta \text {-cyclodextrin (RAMEB) }\end{array}$ & $\begin{array}{l}\text { Anti-inflammatory } \\
\text { antioxidant } \\
\text { anti-fibrotic effects }\end{array}$ & [122] \\
\hline
\end{tabular}

The $\mathrm{Al}(\mathrm{III}), \mathrm{Ga}(\mathrm{III})$ and $\mathrm{In}(\mathrm{III})$ complexes with chrysin and also the titanium(IV), iron(III) and manganese(II) complexes of chrysin- $4^{\prime}$-sulfonate are known, but their activity has not been tested [114,115]. Furthermore, the complexation of chrysin with $\mathrm{Pb}$ (II) [115] and vanadyl(IV) [116] was described with antioxidant activity.

Another method is complexation between chrysin and amino-appended $\beta$-cyclodextrins. This is proven to increase the solubility to $4411.98 \mu \mathrm{g} \mathrm{mL}^{-1}$. The complexation also improved the antioxidant activity and cytotoxicity against cancer cell lines (A549, HT-29, HCT116) [122]. Ignat et al. [122] described biocompatible chrysin- $\beta$-cyclodextrin complexes characterized improved pharmacological effects.

\section{Innovative Ways of Chrysin Delivery}

Because chrysin in the form of aglycone is poorly soluble in water [123], the in vivo studies on improvement of its absorption by using various carriers have been undertaken. It was confirmed that chrysin complexes with methylated $\beta$-cyclodextrin, obtained by lyophilization, were highly effective to enhance chrysin permeability through the Caco-2 monolayers [124], and were not cytotoxic to the cancer cells (Table 3). Also, the cyclodextrin complexes of chrysin containing $\beta$-cyclodextrin ( $\beta$-CD), hydroxypropyl- $\beta$-cylcodextrin (HPBCD) and sulfobutylether- $\beta$-cylcodextrin (SBECD) after 30 min of incubation were not toxic to Caco-2 cells at the concentration of up to $100 \mu \mathrm{M}$. Whereas, at the concentration of $200 \mu \mathrm{M}$ the cell viability decreased below $80 \%$. There are also attempts to synthesize chrysinpolyvinylpyrrolidone microparticles by encapsulation using the supercritical antisolvent (SAS) process, in order to increase therapeutic efficacy in cancer treatment. The most recent research indicate that such constructs have higher antiproliferative activity against MDA-MB-231 breast cancer cell line compared with chrysin, which is attributed to their better solubility under physiological conditions [125]. Chrysin nanocapsules based on polylactic-glycolic acid (PLGA) can find application also as effective anti-glycemic and anti-hyperlipidemic agents [126]. There is also ongoing research into employment of phospholipid chrysin carriers for control of blood sugar in mice with type 2 diabetes [127]. Moreover, chrysin in combination with well-known anticancer chemotherapeutics used in the first-line cancer treatment, such as 5 fluorouracil, co encapsulated with the use of PLGA-PEG-PLGA copolymer may be an important strategy to improve therapeutic efficacy in cancer therapy, including human colon cancer (HT-29) [128]. There is also some evidence that chrysin-loaded nanoliposomes, administered at the doses of 2.5 and $5 \mathrm{mg} \mathrm{kg}^{-1}$ to mice (in vivo study) alleviate the symptoms of the cadmium-induced toxicity. They improve deposition of antioxidant minerals, modulate liver enzymes, alleviate hepatic oxidative 
stress, and improve the morphohistological structure of jejunum (height and width of the intestinal villi) [129].

Table 3. New chrysin delivery systems.

\begin{tabular}{|c|c|c|c|}
\hline Pharmaceutical Form & Physicochemical Characteristics & Activity & Ref. \\
\hline $\begin{array}{c}\text { Chrysin complexes with methylated } \\
\beta \text {-cyclodextrin }\end{array}$ & $\begin{array}{l}\text { Solubility increment: } \\
4.37-8.04\end{array}$ & $\begin{array}{l}\text { High peremetion through the } \\
\text { Caco- } 2 \text { monolayer }\end{array}$ & [124] \\
\hline $\begin{array}{l}\text { chrysin-polyvinylpyrrolidone } \\
\text { sub-microparticles }\end{array}$ & size of $273.7 \mathrm{~nm}$ & $\begin{array}{l}\text { antiproliferative effect } \\
\text { (MDA-MB-231 cells) }\end{array}$ & [125] \\
\hline PLGA-chrysin nanocapsules & $\begin{array}{l}\text { Size: } 176 \mathrm{~nm} \\
\text { Polydispersity index: } 0.22 \text { negative } \\
\text { zeta potential } \\
\text { Drug entrapment efficiency: } 87.1 \%\end{array}$ & $\begin{array}{l}\text { Anti-glycemic and } \\
\text { anti-hyperlipidemic agent }\end{array}$ & [126] \\
\hline Phospholipid-chrysin carriers & Egg phospholipid: chrysin 1:3 & Antidiabetic & [127] \\
\hline $\begin{array}{c}\text { Chrysin-5-fluorouracil-PLGA-PEG- } \\
\text { PLGA } \\
\text { nanocapsules }\end{array}$ & $\begin{array}{l}\text { Combination index: } 0.35 \\
\text { Zeta potential }(\mathrm{mv}):-12.8 \pm 4.0 \\
\text { Size: } 40 \mathrm{~nm}\end{array}$ & Anticancer (HT-29 cells) & [128] \\
\hline Nanoliposome-loaded chrysin (NLC) & $\begin{array}{l}\text { Size: } 185.1 \mathrm{~nm} \\
\text { Polydispersity index: } 0.26\end{array}$ & $\begin{array}{l}\text { Alleviated the symptoms of } \\
\text { cadmium-induced toxicity in mice } \\
\text { in doses } 2.5 \text { and } 5 \mathrm{mg} / \mathrm{kg}\end{array}$ & [129] \\
\hline PLGA-PEG-chrysin nanoparticles & Size: $50-140 \mathrm{~nm}$ & $\begin{array}{l}\text { Enhanced delivery to SW480 } \\
\text { colorectal cancer cells } \\
\mathrm{IC}_{50}=42 \mu \mathrm{M}(24 \mathrm{~h}) \\
\mathrm{IC}_{50}=36 \mu \mathrm{M}(48 \mathrm{~h}) \\
\mathrm{IC}_{50}=33 \mu \mathrm{M}(72 \mathrm{~h})\end{array}$ & [130] \\
\hline
\end{tabular}

Size: $65-90 \mathrm{~nm}(\mathrm{TEM})$

Size: 77 nm (AFM)

Chrysin-loaded PLGA

Polydispersity index: 0.084 Zeta potential $(\mathrm{mv}):-9.33 \pm 0.5$ $(\mathrm{pH}=6.8)$
CHR-NPs squelched OVA-induced pulmonary histopathological alterations, inflammatory cell influx, Th2-cytokine IL(-4, -5 and -13)

BALF levels and serum (IgE), as well as pro-inflammatory cytokines

(TNF- $\alpha, I L-1 \beta$, IL-6, IL-18) in both serum and lung tissue more potently than free chrysin (50 mg/kg body weight)
Chrysin-loaded PLGA-PEG nanoparticles
Size: $233 \mathrm{~nm}$

Polydispersity: 0.145 Zeta potential $(\mathrm{mv}):-6.2 \pm 2.5$

Size ranging between: $2.4-24.7 \mu \mathrm{m}$ Zeta potential $(\mathrm{mv})$ : $(-18.1)-(-14.1)$
Antitumor (B16F10 cells)

$$
\begin{gathered}
\text { Anticancer (MDA-MB } 231 \text { cells) } \\
\mathrm{IC}_{50}=149.19 \mu \mathrm{M} \\
\mathrm{IC}_{50}=312.18 \mu \mathrm{M}
\end{gathered}
$$

Low (up to $2 \%$ ) hemolytic

percentages at concentrations between 5 and $500 \mu \mathrm{g} \cdot \mathrm{mL}^{-1}$

$\mathrm{IC}_{50}$-compound concentration leading $50 \%$ inhibition of cell proliferation. CHR-NPs—chrysin nanoparticles. BALF-bronchoalveolar lavage fluid. TEM-transmission electron microscopy. AFM—atomic force microscope.

The nano-encapsulation of curcumin and chrysin enhanced delivery of these compounds to SW480 colorectal cancer cells [130]. Furthermore, it is known activity of chrysin-PLGA nanoparticles, orally administrated, in ameliorating allergic asthma progression [131].

Also co-encapsulated curcumin and chrysin in PLGA-PEG nanoparticles inhibited the melanoma B16F10 tumor growth and decreased gene expression (TERT - ang. telomerase reverse transcriptase, MMP-9 - ang. matrix metallopeptidase 9, and MMP-2) [132]. Halevas et al. [133] prepared novel chrysin-loaded poly( $\varepsilon$-caprolactone) and poly(3-hydroxybutyrate) 
microcarriers, containing the poly(vinyl alcohol) as stabilizer with sizes between 2.4 and $24.7 \mu \mathrm{m}$.

Designing new delivery systems for chrysin is improving its pharmacological properties and biodistribution. Despite the many advantages of the carriers used heretofore, they also have numerous disadvantages and limitations. One of them is quick elimination from the circulation or unfavorable pharmacokinetic features. Protein carriers, in turn, are characterized by a short biological half-life, low stability under physiological conditions and immunogenicity. Therefore, it becomes necessary to undertake detailed research on the use of, for example, non-toxic cosolubilizers as auxiliary substances, as well as tropic molecules that recognize the target site, in order to support the future development of personalized medicine.

\title{
6. Conclusions
}

Polyphenols are a very large group of natural compounds that are a part of the human diet. Due to their structural diversity, they also have diverse pharmacological activities. Chrysin, which is found among others in citrus fruits, honey and propolis, has a wide range of biological activities, including anticancer, antioxidant, hepatoprotective, antiviral, neuroprotective and anti-anxiety ones. It is also an adjuvant for some drugs.

Several investigations have been aimed at enhancing chrysin's water solubility to achieve higher plasmatic concentrations and decrease the gastric side-effects of some pharmaceuticals. New chrysin delivery formulations have shown successful results.

As methods for improvement, the synthesis of effective chrysin analogs or preparations dedicated to different application routes-such as cancer, dermal or oral route formulations-have also been proposed.

These formulations include different types of polymers and other substances intended to deliver chrysin slowly to the target site. In this area, the use of nanotechnology becomes of special relevance, and several attempts have been undertaken to improve the chrysin release profile.

Although the metabolic pathways of chrysin - both in vitro and in vivo-are known, little is known about the influence of its biotransformation products on the human body. A detailed biological study is needed for new chrysin derivatives with high antioxidant activity.

Author Contributions: Conceptualization, M.S.-G.; writing-original draft preparation, M.S.-G.; writing-review and editing, M.S.-G., A.B.-B. and M.M.; visualization, M.S.-G. and A.B.-B. All authors have read and agreed to the published version of the manuscript.

Funding: M.S.-G. acknowledges support from the National Science Centre NCN Poland (Grant SONATA 16 number: 2020/39/D/NZ9/02023) and also would like to thank the Polish Ministry of Science and Higher Education (currently the Polish Ministry of Education and Science) for financial support under the MNiSW scholarship for outstanding young researchers (STYP/15/0763/E$546 / 2020)$. The funders had no role in study design, data collection or analysis, the decision to publish or the preparation of the manuscript.

Institutional Review Board Statement: Not applicable.

Informed Consent Statement: Not applicable.

Data Availability Statement: All data are publicly available.

Conflicts of Interest: The authors declare no conflict of interest.

\author{
Abbreviations \\ ALP alkaline phosphatase \\ ALT alanine aminotransferase \\ ANXA2 annexin A2 \\ AST aspartate aminotransferase \\ BALF bronchoalveolar lavage fluid \\ $\beta$-CD $\beta$-cyclodextrin
}




$\begin{array}{ll}\text { CCL5 } & \text { C-C motif chemokine ligand 5 } \\ \text { CNV } & \text { choroidal neovascularization } \\ \text { ERK } & \text { extracellular signal-regulated kinase } \\ \text { HAS } & \text { human serum albumin } \\ \text { HPBCD } & \text { hydroxypropyl- } \beta \text {-cylcodextrin } \\ \text { HRV } & \text { human rhinoviruses } \\ \text { INR } & \text { international normalized ratio } \\ \text { LDH } & \text { lactate dehydrogenase } \\ \text { NAFLD } & \text { non-alcoholic fatty liver disease } \\ \text { NF-kB } & \text { nuclear factor kappa B cells } \\ \text { PEG } & \text { polyethylene glycol } \\ \text { ROS } & \text { reactive oxygen species } \\ \text { TGF- } \beta 1 & \text { transforming growth factor beta 1 } \\ \text { VEGF } & \text { vascular endothelial growth factor } \\ \text { VLDL } & \text { very-low-density lipoproteins }\end{array}$

\section{References}

1. Chen, S.; Liu, J.; Dong, G.; Zhang, X.; Liu, Y.; Sun, W.; Liu, A. Flavonoids and caffeoylquinic acids in Chrysanthemum morifolium Ramat flowers: A potentially rich source of bioactive compounds. Food Chem. 2021, 344, 128733. [CrossRef] [PubMed]

2. Zhang, T.; Qiu, F.; Chen, L.; Liu, R.; Chang, M.; Wang, X. Identification and in vitro anti-inflammatory activity of different forms of phenolic compounds in Camellia oleifera oil. Food Chem. 2021, 344, 128660. [CrossRef]

3. Tian, C.; Liu, X.; Chang, Y.; Wang, R.; Lv, T.; Cui, C.; Liu, M. Investigation of the anti-inflammatory and antioxidant activities of luteolin, kaempferol, apigenin and quercetin. Afr. J. Bot. 2021, 137, 257-264. [CrossRef]

4. Stompor, M.; Świtalska, M.; Wietrzyk, J. The influence of a single and double biotinylation of xanthohumol on its anticancer activity. Acta Bioch. Pol. 2019, 66, 559-565. [CrossRef]

5. Jia, X.; Jia, M.; Yang, Y.; Wang, D.; Zhou, F.; Zhang, W.; Huang, X.; Guo, W.; Cai, D.; Chen, H.; et al. Synthesis of novel baicalein amino acid derivatives and biological evaluation as neuroprotective agents. Molecules 2019, 24, 3647. [CrossRef] [PubMed]

6. Oh, T.W.; Do, H.J.; Jeon, J.H.; Kim, K. Quercitrin inhibits platelet activation in arterial thrombosis. Phytomedicine $2021,80,153363$. [CrossRef]

7. Kataoka, J.; Saeki, A.; Hasebe, A.; Shibata, K.I.; Into, T. Naringenin suppresses Toll-like receptor 2-mediated inflammatory responses through inhibition of receptor clustering on lipid rafts. Food Sci. Nutr. 2021, 9, 963-972. [CrossRef]

8. Stompor, M.; Uram, Ł.; Podgórski, R. In vitro effects of 8-prenylnaringenin and naringenin on fibroblasts and glioblastoma cells-cellular accumulation and cytotoxicity. Molecules 2017, 22, 1092. [CrossRef] [PubMed]

9. Shendge, A.K.; Chaudhuri, D.; Mandal, N. The natural flavones, acacetin and apigenin, induce Cdk-cyclin mediated G2/M phase arrest and trigger ROS-mediated apoptosis in glioblastoma cells. Mol. Biol. Rep. 2021, 48, 539-549. [CrossRef]

10. Wang, N.; Wang, L.; Yang, J.; Wang, Z.; Cheng, L. Quercetin promotes osteogenic differentiation on antioxidant responses of mouse bone mesenchymal stem cells through activation of the AMPK/SIRT1 signaling pathway. Phytother. Res. 2021. [CrossRef]

11. Wu, Z.; Fan, Q.; Miao, Y.; Tian, E.; Ishfaq, M.; Li, J. Baicalin inhibits inflammation caused by coinfection of Mycoplasma gallisepticum and Escherichia coli involving IL signaling pathway. Poultry Sci. 2020, 99, 5472-5480. [CrossRef]

12. Liu, T.; Xu, J.; Wu, Y.; Li, X.; Ding, D.; Ma, D.; Yao, M.; Wei, W.; Zhang, W.; Wang, S.; et al. Beneficial effects of baicalein on a model of allergic rhinitis. Acta Pharm. 2020, 70, 35-47. [CrossRef]

13. Yue, S.; Xue, N.; Li, H.; Huang, B.; Chen, Z.; Wang, X. Hepatoprotective effects of apigenin against liver injury via the noncanonical NF-kB pathway in vivo and in vitro. Inflammation 2020, 43, 1634-1648. [CrossRef] [PubMed]

14. Ding, Y.M.; Lin, J.T.; Fang, L.M.; Lou, Z.Q.; Liang, G.N.; Zhang, X.Y.; Li, A.Q.; Zhang, X. The neuroprotective effects of apigenin against OGD/R injury in rat hippocampal neurons. Pak. J. Pharm. Sci. 2020, 33, 1527-1533. [PubMed]

15. Chai, G.R.; Liu, S.; Yang, H.W.; Chen, X.L. Quercetin protects against diabetic retinopathy in rats by inducing heme oxygenase-1 expression. Neural. Regen. Res. 2021, 16, 1344-1350. [PubMed]

16. Kim, S.; Woo, E.R.; Lee, D.G. Apigenin promotes antibacterial activity via regulation of nitric oxide and superoxide anion production. J. Basic Microbiol. 2020, 60, 862-872. [PubMed]

17. Luo, Z.; Kuang, X.P.; Zhou, Q.Q.; Yan, C.Y.; Li, W.; Gong, H.B.; Kurihara, H.; Li, W.X.; Li, Y.F.; He, R.R. Inhibitory effects of baicalein agains herpex simplex virus type 1. Acta Pharm. Sin. B. 2020, 10, 2323-2338. [CrossRef] [PubMed]

18. Xu, X.; Miao, J.; Shao, Q.; Gao, Y.; Hong, L. Apigenin suppresses influenza A virus-induced RIG-I activation and viral replication. J. Med. Virol. 2020, 92, 3057-3066. [CrossRef] [PubMed]

19. Gremski, L.A.; Coelho, A.L.K.; Santos, J.S.; Daguer, H.; Molognoni, L.; do Prado-Silva, L.; Sant'Ana, A.S.; da Silva Rocha, R.; da Silva, M.C.; Cruz, A.G.; et al. Antioxidants-rich ice cream containing herbal extracts and fructooligossaccharides: Manufacture, functional and sensory properties. Food Chem. 2019, 298, 125098. [CrossRef] [PubMed]

20. Chan, C.W.; Deadman, B.J.; Manley-Harris, M.; Wilkins, A.L.; Alber, D.G.; Harry, E. Analysis of the flavonoid component of bioactive New Zealand manuka (Leptospermum scoparium) honey and the isolation, characterization and synthesis of an unusual pyrrole. Food Chem. 2013, 141, 1772-1781. [CrossRef] [PubMed] 
21. Wożniak, M.; Mrówczyńska, L.; Kwaśniewska-Sip, P.; Waśkiewicz, A.; Nowak, P.; Ratajczak, I. Effect of the solvent on propolis phenolic profile and its antifungal, antioxidant, and in vitro cytoprotective activity in human erythrocytes under oxidative. Molecules 2020, 25, 4266. [CrossRef]

22. Lopez, A.P.; Galuch, M.B.; Petenuci, M.E.; Oliveira, J.H.; Canesin, E.A.; Schneider, V.V.A.; Visentainer, J.V. Quantification of phenolic compounds in ripe and unripe bitter melons (Momordica charantia) and evaluation of the distribution of phenolic compounds in different parts of the fruit by UPLC-MS/MS. Chem. Papers 2020, 74, 2613-2625. [CrossRef]

23. Sharma, P.; Kumari, A.; Gulati, A.; Krishnamurthy, S.; Hemalatha, S. Chrysin isolated from Pyrus pashia fruit ameliorates convulsions in experimental animals. Nutr. Neurosci. 2019, 22, 569-577. [CrossRef] [PubMed]

24. Zhang, Y.G.; Kan, H.; Chen, S.X.; Thakur, K.; Wang, S.; Zhang, J.G.; Shang, Y.F.; Wei, Z.J. Comparison of phenolic compounds extracted from Diaphragma juglandis fructus, walnut pellicle and flowers of Jugland regia using methanol, ultrasonic wave, and enzyme assisted-extraction. Food Chem. 2020, 321, 126672. [CrossRef] [PubMed]

25. Taha, G.A.; Abdel-Farid, I.B.; Elgebaly, H.A.; Mahalel, U.A.; Sheded, M.G.; Bin-Jumah, M.; Mahmoud, A.M. Metabolomic profiling and antioxidant, anticancer and antimicrobial activities of Hyphaene thebaica. Processes 2020, 8, 266. [CrossRef]

26. Hu, Y.; Jiao, L.; Jiang, M.H.; Yin, S.; Dong, P.; Zhao, Z.M.; Yang, D.P.; Ho, P.T.; Wang, D.M. A new C-glycosyl flavone and a new neolignan glycoside from Passiflora edulis Sims peel. Nat. Prod. Res. 2018, 32, 2312-2318. [CrossRef]

27. Shi, J.W.; Li, Z.Z.; Wu, J.S.; Jin, W.Y.; Chang, X.Y.; Sun, H.; Dong, L.; Jiang, Z.P.; Shi, Y. Identification of the bioactive components of Banxia Xiexin Decoction that protect against CPT-11-induced intestinal toxicity via UPLC-based spectrum-effects relationship analyses. J. Ethnopharmacol. 2021, 266, 113421. [CrossRef] [PubMed]

28. Eshbakova, K.A.; Toshmatov, Z.O.; Yili, A.; Aisa, H.A.; Abdullaev, N.D. Flavonoid galacturonides and glucuronide from the aerial part of Scutellaria schachristanica. Chem. Nat. Compd. 2013, 49, 103-105. [CrossRef]

29. Kamat, S.; Kumari, M.; Sajna, K.V.; Jayabaskaran, C. Endophytic fungus, Chaetomium globosum, associated with marine green alga, a new sources of chrysin. Sci. Rep. 2021, 10, 18726. [CrossRef] [PubMed]

30. Larit, F.; León, F.; Benyahia, S.; Cutler, S.J. Total phenolic and flavonoid content and biological activities of extracts and isolated compounds of Cytisus villosus pourr. Biomolecules 2019, 9, 732. [CrossRef]

31. Khalil, M.A.; El-Sabbagh, M.S.; El Naggar, E.B.; El-Erian, R.H. Antibacterial activity of Salvadora persica against oral pathogenic bacteria isolated. Niger. J. Clin. Pract. 2019, 22, 1378-1387. [CrossRef] [PubMed]

32. Gharari, Z.; Bagheri, K.; Danafar, H.; Sharafi, A. Enhanced flavonoid production in hairy root cultures of Scutellaria bornmuelleri by elicitor induced over-expression of MYB7 and FNSП2 genes. Plant. Physiol. Biochem. 2020, 148, 35-44. [CrossRef]

33. Zanella, L.; Gismondi, A.; Di Marco, G.; Braglia, R.; Scuderi, F.; Redi, E.L.; Galgani, A.; Canini, A. Induction of antioxidant metabolites in Moringa oleifera callus by abiotic stresses. J. Nat. Prod. 2019, 82, 2379-2386. [CrossRef]

34. Walle, T.; Otake, Y.; Brubaker, J.A.; Walle, U.K.; Halushka, P.V. Disposition and metabolism of the flavonoid chrysin in normal volunteers. Br. J. Clin. Pharmacol. 2001, 51, 143-146. [PubMed]

35. Liu, X.N.; Cheng, J.; Zhu, X.X.; Zhang, G.H.; Yang, S.C.; Guo, X.X.; Jiang, H.F.; Ma, Y.H. De novo biosynthesis of multiple pinocembrin derivatives in Saccharomyces cerevisiae. ASC Synth. Biol. 2020, 9, 3042-3051. [CrossRef] [PubMed]

36. Sordon, S.; Madej, A.; Popłoński, J.; Bartmańska, A.; Tronina, T.; Brzezowska, E.; Juszczyk, P.; Huszcza, E. Regioselective ortho-hydroxylations of flavonoids by yeast. J. Agric. Food Chem. 2016, 64, 5525-5530. [CrossRef]

37. Sordon, S.; Popłoński, J.; Tronina, T.; Huszcza, E. Regioselective O-glycosylation of flavonoids by fungi Beauveria bassiana, Absidia coerulea and Absidia glauca. Bioorg. Chem. 2019, 93, 102750. [CrossRef] [PubMed]

38. Ge, S.; Gao, S.; Yin, T.; Hu, M. Determination of Pharmacokinetics of Chrysin and its conjugates in wild-type FVB and Bcrp1 knockout mice using a validated LC-MS/MS method. J. Agric. Food Chem. 2015, 63, 2902-2910. [CrossRef]

39. Kimura, Y.; Ito, H.; Ohnishi, R.; Hatano, T. Inhibitory effects of polyphenols on human cytochrome P450 3A4 and 2C9 activity. Food Chem. Toxicol. 2010, 48, 429-435. [CrossRef] [PubMed]

40. Bojić, M.; Kondža, M.; Rimac, H.; Benković, G.; Maleš, Ž. The effect of flavonoid aglycones on the CYP1A2, CYP2A6, CYP2C8 and CYP2D6 enzymes activity. Molecules 2019, 24, 3174. [CrossRef]

41. Labib, S.; Erb, A.; Kraus, M.; Wickert, T.; Richling, E. The pig caecum model: A siutable tool to study the intestinal metabolism of flavonoids. Mol. Nutr. Food Res. 2004, 48, 326-332. [CrossRef]

42. Sherif, I.O.; Al-Mutabagani, L.A.; Sabry, D.; Elsherbiny, N.M. Antineoplastic activity of chrysin against human hepatocellular carcinoma: New insight on GPC3/SULF2 axis and lncRNA-AF085935 expression. Int. J. Mol. Sci. 2020, 21, 7642. [CrossRef]

43. Xie, Y.; Peng, X. Effects of chrysin on the apoptosis in oral squamous carcinoma KB cell line and the underlying mechanisms. J. Cent. S Univ. Med. Sci. 2019, 44, 522-527.

44. Chen, H.Y.; Jiang, Y.W.; Kuo, C.L.; Way, T.D.; Chou, Y.C.; Chang, Y.S.; Chung, J.G. Chrysin inhibit human melanoma A375.S2 cell migration and invasion via affecting MAPK signaling and NF-kB signaling pathway in vitro. Environ. Toxicol. 2019, 34, 434-442. [CrossRef]

45. Ryu, S.; Bazer, F.W.; Lim, W.; Song, G. Chrysin leads to cell death in endometriosis by regulation of endoplasmic reticulum stress and cytosolic calcium level. J. Cell Physiol. 2019, 234, 2480-2490. [CrossRef] [PubMed]

46. Stompor, M.; Świtalska, M.; Wietrzyk, J. Synthesis and biological evaluation of acyl derivatives of hydroxyflavones as potent antiproliferative agents against drug resistance cell lines. Z Naturforsch. C J. Biosci. 2018, 73, 87-93. [CrossRef]

47. Wu, B.L.; Wu, Z.W.; Yang, F.; Shen, X.F.; Wang, L.; Chen, B.; Li, F.; Wang, M.K. Flavonoids from the seeds of Oroxylum indicum and their anti-inflammatory and cytotoxic activities. Phytochem. Lett. 2019, 32, 66-69. [CrossRef] 
48. Zhang, C.; Yu, M.; Hao, F.; Dong, A.; Chen, D.; Zhang, K. Chrysin inhibits growth and induced apoptosis of anaplastic thyroid cancer cells via Notch-1/Slug/PUMA signals. Int. J. Clin. Exp. Pathol. 2016, 9, 9038-9047.

49. Boothapandi, M.; Ravichandran, R. Antiproliferative activity of chrysin (5,7-dihydroxyflavone) from Indigofera tinctoria on human epidermoid carcinoma (A431) cells. Eur. J. Integr Med. 2018, 24, 71-78. [CrossRef]

50. Wang, J.; Wang, H.; Sun, K.; Wang, X.; Pan, H.; Zhu, J.; Ji, X.; Li, X. Chrysin suppresses proliferation, migration, and invasion in glioblastoma cell lines via mediating the ERK/Nrf2 signaling pathway. Drug Des. Dev. Ther. 2018, 12, 721-733. [CrossRef]

51. Xue, C.; Chen, Y.; Hu, D.N.; Iacob, C.; Lu, C.; Huang, Z. Chrysin induced cell apoptosis in human uveal melanoma cells via intrinsic apoptosis. Oncol. Lett. 2016, 12, 4813-4820. [CrossRef]

52. Salama, A.A.A.; Allam, R.M. Promising targets of chrysin and daidzein in colorectal cancer: Amphiregulin, CXCL1 and MMP-9. Eur. J. Pharm. 2021, 892, 173763. [CrossRef]

53. Liu, Y.M.; Li, Y.; Xiao, J.; Zhang, Q.Z.; Song, J.X. Design, synthesis, and preliminary biological evaluation of chrysin amino acid derivatives that induce apoptosis and suppress cell migration. J. Asian Nat. Prod. Res. 2020, 22, 547-561. [CrossRef]

54. Wang, H.J.; Zhou, Y.Y.; Liu, X.L.; Zhang, W.H.; Chen, S.; Liu, X.W.; Zhou, Y. Regioselective synthesis and evaluation of 2-amino 3-cyano chromene-chrysin hybrids as potential anticancer agents. Bioorg. Med. Chem Lett. 2020, 30, 127087. [CrossRef]

55. Mayer, S.; Keglevich, P.; Ábrányi-Balogh, P.; Szigetvári, Á.; Dèkány, M.; Szántay, C.J.; Hazai, L. Synthesis and in vitro anticancer evaluation of novel chrysin and 7-aminochrysin derivatives. Molecules 2020, 25, 888. [CrossRef] [PubMed]

56. Mistry, B.M.; Patel, R.V.; Keum, Y.S.; Kim, D.H. Chrysin-benzothiazole conjugates as antioxidant and anticancer agents. Bioorg. Med. Chem. 2015, 25, 5561-5565. [CrossRef] [PubMed]

57. Chen, N.; Wang, R.; Lu, L.J.; Yan, L.J.; Bai, L.L.; Fu, Y.; Wang, Y.; Peng, D.Q.; Chen, X.; Wang, C.H.; et al. Synthesis of chrysin derivatives and screening of antitumor activity. J. Asian Nat. Prod. Res. 2020, 22, 444-451. [CrossRef]

58. Castañeda-Arriaga, R.; Marino, T.; Russo, N.; Alvarez-Idaboy, J.R.; Galano, A. Chalcogen effects on the primary antixidant activity of chrysin and quercetin. New J. Chem. 2020, 44, 9073-9082. [CrossRef]

59. Marzec, E.; Świtalska, M.; Winiewska-Szajewska, M.; Wójcik, J.; Wietrzyk, J.; Maciejewska, A.M.; Poznański, J.; Mieczkowski, A. The halogenation of natural flavonoids, baicalein and chrysin, enhances their affinity to human protein kinase CK2. IUBMB Life 2020, 72, 1250-1261. [CrossRef]

60. Liu, D.; Zhang, Q.; Zhang, L.; Yu, W.; Long, H.; He, J.; Liu, Y. Novel photosensitizing properties of porphyrin-chrysin derivatives with antitumor activity in vitro. J. Chem. Res. 2020. [CrossRef]

61. Mohos, V.; Fliszár-Nyúl, E.; Schilli, G.; Hetènyi, C.; Lemli, B.; Kunsági-Mátè, S.; Bognár, B.; Poór, M. Interaction of chrysin and its main conjugated metabolites chrysin-7-sulfate and chrysin-7-glucuronide with serum albumin. Int. J. Mol. Sci. 2018, 19, 4073. [CrossRef]

62. Sassi, A.; Boubaker, J.; Loussaief, A.; Jomaa, K.; Ghedira, K.; Chekir-Ghedira, L. Protective effects of chrysin, a dietary flavones against genotoxic and oxidative damage induced by mitomycin $\mathrm{C}$ in Balb/C mice. Nutr. Cancer. 2020. [CrossRef]

63. Ghamkhari, A.; Pouyafar, A.; Salehi, R.; Rahbarghazi, R. Chrysin and docetaxel loaded biodegradable micelle for combination chemotherapy of cancer stem cell. Pharm. Res. 2019, 36, 165. [CrossRef]

64. Wang, J.N.; Li, X.; Chen, M.F.; Wang, F.Y.; Xiong, X.K.; Chen, X.J.; Yang, M.L.; Huang, J.M. Sensitization of chrysin on the apoptosis induced by cisplatin or camptothecin in hepatoma cell lines (Hep G2). Chin. Pharm. J. 2016, 51, 2088-2093.

65. Temel, Y.; Caglayan, C.; Ahmed, B.N.; Kandemir, F.M.; Ciftci, M. The effects of chrysin and naringin on cyclophosphamideinduced erythrocyte damage in rats: Biochemical evaluation of some enzyme activities in vivo and in vitro. Naun Schmiedeberg Archiv Pharmacol. 2020. [CrossRef] [PubMed]

66. Taslimi, P.; Kandemir, F.M.; Demir, Y.; Ileriturk, M.; Temel, Y.; Caglayan, C.; Gulcin, I. The antidiabetic and anticholinergic effects of chrysin on cyclophosphamide-induced multiple organ toxicity in rats: Pharmacological evaluation of some metabolic enzyme activities. J. Biochem. Mol. Toxicol. 2019, 33, e22313. [CrossRef]

67. Belhan, S.; Çomakli, S.; Küçükler, S.; Gülyüz, F.; Yildirim, S.; Yener, Z. Effect of chrysin on methotrexate-induced testicular damage in rats. Andrologia 2019, 51, e13145. [CrossRef]

68. Darendelioglu, E. Neuroprotective effects of chrysin on diclofenac-induced apoptosis in SH-SY5Y cells. Neurochem. Res. 2020, 45, 1064-1071. [CrossRef]

69. Çelik, H.; Kucukler, S.; Çomakli, S.; Caglayan, C.; Özdemir, S.; Yardim, A.; Karaman, M.; Kandemir, F.M. Neuroprotective effects of chrysin on isoniazid-induced neurotoxicity via suppression of oxidative stress, inflammation and apoptosis in rats. NeuroToxicology 2020, 81, 197-208. [CrossRef]

70. Pingili, R.B.; Pawar, A.K.; Challa, S.R. Systemic exposure of paracetamol (acetaminophen) was enhanced by quercetin and chrysin co-administration in Wistar rats and in vitro model: Risk of liver toxicity. Drug Dev. Ind. Pharm. 2015, 41, 1793-1800. [CrossRef] [PubMed]

71. Song, Y.; Wu, W.; Sheng, L.; Jiang, B.; Li, X.; Cai, K. Chrysin ameliorates hepatic steatosis induced by a diet deficient in methionine and choline by inducing the secretion of hepatocyte nuclear factor $4 \alpha$-dependent very low-density lipoprotein. J. Biochem. Mol. Toxicol. 2020. [CrossRef]

72. Mohammadi, A.; Kazemi, S.; Hosseini, M.; Najafzadeh Varzi, H.; Feyzi, F.; Morakabati, P.; Moghadamnia, A.A. Chrysin effect in prevention of acetaminophen-induced hepatotoxicity in rat. Chem. Res. Toxicol. 2019, 32, 2329-2337. [CrossRef] 
73. Ye, M.H.; Xu, M.T.; Fan, S.H.; Zhang, M.J.; Zhou, B.; Yang, S.M.; Wei, W.H.; Ji, C.; Ji, J.; Ji, F.B. Protective effects of three propolis-abundant flavonoids against ethanol-induced injuries in HepG2 cells involving the inhibition of ERK1/2-AHR-CYP1A1 sygnaling pathway. J. Funct. Food. 2020, 73, 104166. [CrossRef]

74. Tahir, M.; Sultana, S. Chrysin modulates ethanol metabolism in Wistar rats: A promising role against organ toxicities. Alcohol. Alcohol. 2011, 46, 383-392. [CrossRef]

75. Pai, S.A.; Munshi, R.P.; Panchal, F.H.; Gaur, I.S.; Juvekar, A.R. Chrysin ameliorates nonalcoholic fatty liver disease in rats. Naunyn-Schmiedeberg's Archiv Pharmacol. 2020, 392, 1617-1628. [CrossRef]

76. Fatemi, I.; Khalili, H.; Mehrzadi, S.; Basir, Z.; Malayeri, A.; Goudarzi, M. Mechanisms involved in the possible protective effects of chrysin against sodium arsenite-induced liver toxicity in rats. Life Sci. 2021, 267, 118965. [CrossRef] [PubMed]

77. Li, H.J.; Wu, N.L.; Pu, C.M.; Hsiao, C.Y.; Chang, D.C.; Hung, C.F. Chrysin alleviates imiquimod-induced psoriasis-like skin inflammation and reduces the release of CCL20 and antimicrobial peptides. Sci. Rep. 2020, 10, 2932. [CrossRef] [PubMed]

78. Song, H.Y.; Kim, W.S.; Mushtaq, S.; Park, J.M.; Choi, S.H.; Cho, J.W.; Lim, S.T.; Byun, E.B. A novel chrysin derivative produced by gamma irradiation attenuates 2,4-dinitrochlorobenzene-induced atopic dermatitis-like skin lesions in Balb/c mice. Food Chem. Toxicol. 2019, 128, 223-232. [CrossRef]

79. Yeo, H.; Lee, Y.H.; Koh, D.; Lim, Y.; Shin, S.Y. Chrysin inhibits NF-kB-dependent CCL5 transcription by targeting I kappa B kinase in the atopic dermatitis-like inflammatory microenvironment. Int. J. Mol. Sci. 2020, 21, 7348. [CrossRef] [PubMed]

80. Choi, J.K.; Jang, Y.H.; Lee, S.; Lee, S.R.; Choi, Y.A.; Jin, M.; Choi, J.H.; Park, J.H.; Park, P.H.; Choi, H.; et al. Chrysin attenuates atopic dermatitis by suppressing inflammation of keratinocytes. Food Chem. Toxicol. 2017, 110, 142-150. [CrossRef]

81. Wu, N.; Fang, J.Y.; Che, M.; Wu, C.J.; Huang, C.C.; Hung, C.F. Chrysin protects epidermal keratinocytes from UVA- and UVB-induced damage. J. Agric. Food Chem. 2011, 59, 8391-84000. [CrossRef]

82. Zhu, L.; Yu, W.G.; Zhao, X.; Lu, Y.H. Anti-photoaging and anti-melanogenesis activities of chrysin. Pharm. Biol. 2015, 54, 2692-2700. [CrossRef]

83. Bortolotto, V.C.; Araujo, S.M.; Pinheiro, F.C.; Poetini, M.R.; de Paula, M.T.; Meichtry, L.B.; de Almeida, F.P.; Musachio, E.A.S.; Guerra, G.P.; Prigol, M. Modulation of glutamate levels and $\mathrm{Na}^{+}, \mathrm{K}^{+}$-ATPase activity contributes to the chrysin memory recovery in hypothyroidism mice. Physiol. Behav. 2020, 222, 112892. [CrossRef]

84. Prajit, R.; Sritawan, N.; Suwannakot, K.; Naewla, S.; Aranarochana, A.; Sirichoat, A.; Pannangrong, W.; Wigmore, P.; Welbat, J.U. Chrysin protects against memory and hippocampal neurogenesis depletion in D-galactose-induced aging in rats. Nutrients 2020, 12, 1100. [CrossRef]

85. Angelopoulou, E.; Pyrgelis, E.S.; Piperi, C. Neuroprotective potential of chrysin in Parkinson's disease: Molecular mechanisms and clinical implications. Neurochem. Int. 2020, 132, 104612. [CrossRef]

86. Song, J.H.; Moon, K.Y.; Lee, S.C.; Kim, S.S. Inhibition of hypoxia-inducible factor- $1 \alpha$ and vascular endothelial growth factor by chrysin in a rat model of choroidal neovascularization. Int. J. Mol. Sci. 2020, 21, 2842. [CrossRef] [PubMed]

87. Del Fabbro, L.; de Gomes, M.G.; Souza, L.C.; Goes, A.R.; Boeira, S.P.; Oliveira, M.S.; Furian, A.F.; Jesse, C.R. Chrysin suppress immune responses and protects from experimental autoimmune encephalomyelitis in mice. J. Neuroimmunol. 2019, $335,577007$. [CrossRef] [PubMed]

88. Car, H.; Fiedorowicz, A.; Żendzian-Piotrowska, M.; Chabowski, A.; Naliwajko, S.K.; Socha, K.; Markiewicz-Żukowska, R.; Omeljaniuk, W.J.; Borawska, M.H. Ceramide and sphingomyelin levels in the rat brain after chrysin intake. Farmacia 2020, 68, 28-34. [CrossRef]

89. Kwon, M.J.; Shin, H.M.; Perumalsamy, H.; Wang, X.; Ahn, Y.J. Antiviral effects and possible mechanisms of action of constituents from Brazilian propolis and related compounds. J. Apicult. Res. 2020, 59, 413-425. [CrossRef]

90. Sadati, S.M.; Gheibi, N.; Ranjbar, S.; Hashemzadehm, M.S. Docking study of flavonoid derivatives as potent inhibitors of influenza H1N1 virus neuraminidas. Biomed. Rep. 2019, 10, 33-38. [PubMed]

91. Song, J.H.; Kwon, B.E.; Jang, H.; Kang, H.; Cho, S.; Park, K.; Ko, H.J.; Kim, H. Antiviral activity of chrysin derivatives against coxackievirus B3 in vitro and in vivo. Biomol. Ther. 2015, 23, 465-470. [CrossRef] [PubMed]

92. Du, Q.; Gu, X.; Cai, J.; Huang, M.; Su, M. Chrysin attenuates allergic airway inflammation by modulating the transcription factors T-bet and GATA-3 in mice. Mol. Med. Rep. 2012, 6, 100-104.

93. Shoieb, S.M.; Esmat, A.; Khalifa, A.E.; Abdel-Naim, A.B. Chrysin attenuates testosterone-induced benign prostate hyperplasia in rats. Food Chem. Toxicol. 2018, 111, 650-659. [CrossRef] [PubMed]

94. Alptekin, H.; Calosir, A.; Ozturk, B.; Ugurlu, C.; Yormaz, S.; Ece, I. The effects of chrysin in an experimental model of acute pancreatitis. Ann. Ital. di Chirurgia 2020, 91, 544-551.

95. Hong, J.S.; Feng, J.H.; Park, J.S.; Lee, H.J.; Lee, J.Y.; Lim, S.S.; Suh, H.W. Antinociceptive effects of chrysin in diabetic neuropathy and formalin-induced pain models. Anim. Cells Syst. 2020. [CrossRef]

96. Puthanveetil, P.; Kong, X.; Bräse, S.; Voros, G.; Peer, W.A. Transcriptome analysis of two structurally related flavonoids; apigenin and chrysin revealed hypocholesterolemic and ketogenic effects in mouse embryonic fibroblasts. Eur. J. Pharmacol. 2021, 893, 173804. [CrossRef] [PubMed]

97. Mei, J.; Yang, R.; Yang, Q.; Wan, W.; Wei, X. Proteomic screening identifies the direct targets of chrysin anti-lipid depot in adipocytes. J. Ethnopharmacol. 2021, 267, 113361. [CrossRef] 
98. Germán-Ponciano, L.J.; Puga-Olguín, A.; De Jesús Rovirosa-Hernández, M.; Caba, M.; Meza, E.; Rodríguez-Landa, J.F. Differential effects of acute and chronic treatment with the flavonoid chrysin on anxiety-like behavior and Fos immunoreactivity in the lateral septal nucleus in rats. Acta Pharm. 2020, 70, 387-397. [CrossRef]

99. Rodríguez-Landa, J.F.; Guillèn-Ruiz, G.; Hernández-López, F.; Cueto-Escobedo, J.; Rivadeneyra-Domínguez, E.; Bernal-Morales, B.; Herrera-Huerta, E.V. Chrysin reduces anxiety-like behavior through action on $\mathrm{GABA}_{\mathrm{A}}$ receptors during metestrus-diestrus in the rat. Behav. Brain Res. 2021, 397, 112952. [CrossRef]

100. Goutman, J.D.; Waxemberg, M.D.; Doñate-Oliver, F.; Pomata, P.E.; Calvo, D.J. Flavonoid modulation of ionic currents mediated by GABA(A) and GABA(C). Eur. J. Pharmacol. 2003, 461, 79-87. [CrossRef]

101. Kseibati, M.O.; Sharawy, M.H.; Salem, H.A. Chrysin mitigates bleomycin-induced pulmonary fibrosis in rats through regulating inflammation, oxidative stress, and hypoxia. Int. Immunopharmacol. 2020, 89, 107011. [CrossRef]

102. Del Fabbro, L.; de Gomes, M.G.; Goes, A.R.; Jesse, C.R. Modulatory response of chrysin supplementation in an experimental autoimmune ecephalomyelitis model: Evaluation of microRNA influence. PharmaNutrition 2021, 15, 100242. [CrossRef]

103. Di Ciaccio, L.S.; Catalano, A.V.; López, P.G.; Rojas, D.; Cristos, D.; Fortunato, R.H.; Salvat, A.E. In vitro antifungal activity of Peltophorum dubium (Spreng.) taub. extracts against Aspergillus flavus. Plants 2020, 9, 438. [CrossRef] [PubMed]

104. Bi, F.; Yong, H.; Liu, J.; Zhang, X.; Shu, Y.; Liu, J. Development and characterization of chitosan and D- $\alpha$-tocopheryl polyethylene glycol 1000 succinate composite films containing different flavones. Food Packag. Shelf Life 2020, 25, 100531. [CrossRef]

105. Xu, X.; Pu, R.; Li, Y.; Wu, Z.; Li, C.; Miao, X.; Yang, W. Chemical compositions of propolis from China and the United States and their antimicrobial activities against Penicillium Notatum. Molecules 2019, 24, 3576. [CrossRef]

106. Majkut, M.; Kwiecińska-Piróg, J.; Wszelaczyńska, E.; Pobereżny, J.; Gospodarek-Komkowska, E.; Wojtacki, K.; Bardczak, T. Antimicrobial activity of heat-treated Polish honeys. Food Chem. 2021, 343, 128561. [CrossRef] [PubMed]

107. Aljaghwani, A.; Allemailem, K.S.; Aljaghwani, L.F.; Alrumaihi, F.; Joseph, R.J.; Khan, A.A.; Aljaghwani, M.; Rahmani, A.H.; Almatroudi, A. Antimicrobial effect of different types of honey on selected ATCC bacteria strains. Pharm. J. 2021, 13, $217-225$.

108. Halevas, E.; Mavroidi, B.; Pelecanou, M.; Hatzidimitriou, A.G. Structurally characterized zinc complexes of flavonoids chrysin and quercetin with antioxidant potential. Inorgan Chim. Acta. 2021, 523, 120407. [CrossRef]

109. Martínez Medina, J.J.; Rodríguez, J.; Mermot, J.; Naso, L.G. Antitumor and antimetastatic effects and safety profile of a new magnesium (II)-chrysin complex. Aust. J. Chem. 2020, 73, 614-626. [CrossRef]

110. Zeng, Y.B.; Yang, N.; Liu, W.S.; Tang, N. Synthesis, characterization and DNA-binding properties of La(III) complex chrysin. J. Inorg. Biochem. 2003, 97, 258-264. [CrossRef]

111. Ravishankar, D.; Salamah, M.; Attina, A.; Pothi, R.; Vallance, T.M.; Javed, M.; Williams, H.F.; Alzahrani, E.M.S.; Kabova, E.; Vaiyapuri, R.; et al. Ruthenium-conjugated chrysin analogues modulate platelet activity, thrombus formation and homeostasis with enhanced efficacy. Sci. Rep. 2017, 7, 5738. [CrossRef]

112. Marques, J.; Silva, A.M.S.; Marques, M.P.M.; Braga, S.S. Ruthenium(II) trithiacyclononane complexes of 7,3', $4^{\prime}$-trihydroxyflavone, chrysin and tectochrysin: Synthesis, characterisation, and cytotoxic evaluation. Inorg. Chim. Acta. 2019, 488, 71-79. [CrossRef]

113. Halevas, E.; Mavroidi, B.; Antonoglou, O.; Hatzidimitriou, A.; Sagnou, M.; Pantazaki, A.A.; Litsardakis, G.; Pelecanou, M. Structurally characterized gallium-chrysin complexes with anticancer potential. Dalton Trans. 2020, 49, 2734-2746. [CrossRef]

114. Pusz, J.; Nitka, B.; Xielińska, A.; Wawer, I. Synthesis and physicochemical properties of the Al(III), Ga(III) and In(III) complexes with chrysin. Microchem. J. 2000, 65, 245-253. [CrossRef]

115. Pusz, J. The titanium(IV), iron(III) and manganese(II) complexes of chrysin-4'-sulfonate. Pol. J. Chem. 2001, 75, 795-801.

116. Wang, Q.; Zhao, H.; Zhu, M.; Gao, L.; Cheng, N. Spectroscopy characterization, theoretical study and antioxidant activities of the flavonoids-Pb(II) complexes. J. Mol. Struct. 2020, 1209, 127919. [CrossRef]

117. Naso, L.; Ferrer, E.G.; Lezama, L.; Rojo, T.; Etcheverry, S.B.; Williams, P. Role of oxidative stress in the antitumoral action of a new vanadyl(IV) complex with the flavonoid chrysin in two osteoblast cell lines: Relationship with the radical scavenger activity. J. Biol. Inorg. Chem. 2010, 15, 889-902. [CrossRef] [PubMed]

118. Gençkal, H.M. New heteroleptic Cu(II) complexes of chrysin with 2,2'-bipyridine and substituted 1,10-phenanthrolines: Synthesis, characterization, thermal stability and antioxidant activity. J. Mol. Struct. 2020, 1209, 127917. [CrossRef]

119. Halevas, E.; Mitrakas, A.; Mavroidi, B.; Athanasiou, D.; Gkika, P.; Antoniou, K.; Samaras, G.; Lialiaris, E.; Hatzidimitriou, A.; Pantazaki, A.; et al. Structurally characterized copper-chrysin complexes display genotoxic and cytotoxic activity in human cells. Inorg. Chim. Acta. 2021, 515, 120062. [CrossRef]

120. León, I.E.; Cadavid-Vargas, J.F.; Tiscornia, I.; Porro, V.; Castelli, S.; Katkar, P.; Desideri, A.; Bollati-Fogolin, M.; Etcheverry, S.B. Oxidovanadium (IV) complexes with chrysin and silibinin: Anticancer activity and mechanism of action in human colon adenocarcinoma model. J. Biol. Inorg. Chem. 2015, 20, 1175-1191. [CrossRef]

121. Song, S.; Gao, K.; Niu, R.; Wang, J.; Zhang, J.; Gao, C.; Yang, B.; Liao, X. Inclusion complexes between chrysin and amino-appended $\beta$-cyclodextrins (ACDs): Binding behavior, water solubility, in vitro antioxidant activity and cytotoxicity. Mater. Sci. Eng. C. 2020, 106, 110161. [CrossRef]

122. Ignat, S.R.; Dinescu, S.; Varadi, J.; Fenyvesi, F.; Nguyen, T.L.P.; Ciceu, A.; Hermenean, A.; Costache, M. Complexation with random methyl- $\beta$-cyclodextrin and (2-hydroxypropyl)- $\beta$-cyclodextrin promotes chrysin effect and potential for liver fibrosis therapy. Materials 2021, 13, 5003. [CrossRef]

123. Dong, X.; Cao, Y.; Wang, N.; Wang, P.; Li, M. Systematic study on solubility of chrysin in different organic solvents: The synergistic effects of multiple intermolecular interactions on the dissolution process. J Mol Liq. 2021, 325, 115180. [CrossRef] 
124. Fenyvesi, F.; Phuong Nguyen, T.L.; Haimhoffer, A.; Rusznyák, A.; Vasvári, G.; Bácskay, I.; Vecsernyès, M.; Ignat, S.R.; Dinescu, S.; Costache, M.; et al. Cyclodextrin complexation improves the solubility and Caco-2 permeability of chrysin. Materials 2020, 13, 3618. [CrossRef] [PubMed]

125. Pan, Y.J.; Xu, P.Y.; Chen, B.Q.; Fu, C.P.; Kankala, R.K.; Chen, A.Z.; Wang, S.B. Supercritical antisolvent process-assisted fabrication chrysin- polyvinylpyrrolidone sub-microparticles for improved anticancer efficiency. J. Supercrit. Fluids 2020, 162, 104847. [CrossRef]

126. El-Hussien, D.; El-Zaafarany, G.M.; Nasr, M.; Sammour, O. Chrysin nanocapsules with dual anti-glycemic and anti-hyperglycemic effects: Chemometric optimization, physiochemical characterization and pharmacodynamic assessment. Int. J. Pharm. 2021, 592, 120044. [CrossRef]

127. Kim, S.M.; Imm, J.Y. The effects of chrysin-loaded phytosomes on insulin resistance and blood sugar control in type 2 diabetic $\mathrm{db} / \mathrm{db}$ mice. Molecules 2020, 25, 5503. [CrossRef] [PubMed]

128. Khaledi, S.; Jafari, S.; Hamidi, S.; Molavi, O.; Davaran, S. Preparation and characterization of PLGA-PEG-PLGA polymeric nanoparticles for co-delivery of 5-fluorouracil and chrysin. J. Biomat. Sci. Polym. E. 2020, 31, 1107-1126. [CrossRef] [PubMed]

129. Beyrami, M.; Karimi, E.; Oskoueian, E. Synthesized chrysin-loaded nanoliposomes improves cadmium-induced toxicity in mice. Environ. Sci. Pollut. Res. 2020, 27, 40643-40651. [CrossRef]

130. Bagheri, R.; Sanaat, Z.; Zarghami, N. Synergistic effect of free and nano-encapsulated chrysin-curcumin on inhibition of hTERT gene expression in SW480 colorectal cancer cell line. Drug Res. 2018, 68, 335-343. [CrossRef]

131. Roy, S.; Manna, K.; Jha, T.; Saha, K.D. Chrysin-loaded PLGA attenuates OVA-induced allergic asthma by modulating TLR/NFkB/NLRP3 axis. Nanomed. Nanotechnol. Biol. Med. 2020, 30, 102292. [CrossRef] [PubMed]

132. Tavakoli, F.; Jahanban-Esfahlan, R.; Seidi, K.; Jabbari, M.; Behzadi, R.; Pilehvar-Soltanahmadi, Y.; Zarghami, N. Effects of nano-encapsulated curcumin-chrysin on telomerase, MMPs, and TIMPs gene expression in mouse B16F10 melanoma tumor model. Artif. Cell Nanomed. B. 2018, 46, 75-86. [CrossRef] [PubMed]

133. Halevas, E.; Kokotidou, C.; Zaimai, E.; Moschona, A.; Lialiaris, E.; Matraki, A.; Lialiaris, T.; Pantazaki, A. Evaluation of the hemocompatibility and anticancer potentialof poly( $\varepsilon$-caprolactone) and poly(3-hydroxybutyrate) microcarriers with encapsulated chrysin. Pharmaceutics 2021, 13, 109. [CrossRef] [PubMed] 